RESEARCH ARTICLE

Murat Kaya ${ }^{1}$

Murat Kabaklioglu ${ }^{1}$

Recep Eroz ${ }^{2}$

${ }^{1}$ Department of Pediatric Surgery,

Duzce University, Medical

Faculty, Duzce, Turkey

${ }^{2}$ Department of Medical

Genetics, Duzce University, Medical Faculty, Duzce, Turkey

Corresponding Author:

Murat Kaya

Department of Pediatric Surgery, Duzce University, Medical Faculty, Duzce,

Turkey

mail:drkayam@gmail.com

Phone: +90 5303244661

Received: 07.09.2020

Acceptance: 02.12.2020

DOI: $10.18521 / \mathrm{ktd} .791532$

Konuralp Medical Journal e-ISSN1309-3878

konuralptipdergi@duzce.edu.tr konuralptipdergisi@gmail.com www.konuralptipdergi.duzce.edu.tr

\section{Clinical Approach to Patients with Klippel-Feil Syndrome} ABSTRACT

Objective: Klippel-Feil Syndrome (KFS) is a congenital syndrome that have short neck, fusion in the at least 2 cervical vertebrae and decrease in neck movements in the classic triad. KFS patients may have higher risk for mechanical spinal cord injury because of unstable cervical segments. Patients should be examined extensively, since many anomalies may accompany KFS. In the current article, we aimed to present our cases with KFS with clinical, radiological and genetic results.

Methods: In this study, a total of 317 cervical MRIs required by Pediatric Surgery between 2012-2019 years with various indications and 90 cervical CT reports in 2019 were evaluated. Information was collected retrospectively with a file scan. Clinical, radiological, biochemical and genetic evaluation of KFS cases were performed.

Results: All of our patients with KFS had Sprengel deformity, cervical fusion anomaly, restricted neck movements, short neck, low hairline and growth retardation. Growth Differentiating Factor 6 (GDF6) gene was negative in all our patients.

Conclusions: The necessity of treatment depends more on the pathologies that may be caused by deformity and other systemic findings. The patient should be cautious and avoid heavy exercise because of neurological deficits seen after minor trauma in patients with KFS.

Keywords: Klippel-Feil Syndrome, Sprengel Deformity, Cervical Fusion Anomaly, Short Neck

\section{Klippel-Feil Sendromlu Hastalara Klinik Yaklaşım \\ ÖZET}

Amaç: Klippel-Feil Sendromu (KFS), klasik triadında kısa boyun, en az 2 servikal omurda füzyon anomalisi ve boyun hareketlerinde azalmanın olduğu konjenital bir malformasyondur. KFS'li hastalar stabil olmayan boyun segmentleri nedeniyle, mekanik olarak yüksek spinal kord hasarı riskine sahiptirler. Bu hastalar, KFS'ye birçok anomalinin eşlik etmesi muhtemel olduğundan kapsamlı bir şekilde muayene edilmelidir. Biz bu çalışmada KFS olgularımızı klinik, radyolojik, biyokimyasal ve genetik sonuçlarıyla sunmayı amaçladık.

Gereç ve Yöntem: 2012-2019 yılları arasında çeşitli endikasyonlarla; Çocuk Cerrahisi kliniği tarafindan istenen toplam 317 servikal MR ve 2019 yll içerisinde çekilen toplam 90 servikal BT raporu değerlendirildi. Saptanan KFS olgularının bilgileri dosya taraması yöntemiyle toplandı. KFS olgularının klinik, radyolojik, biyokimyasal ve genetik değerlendirmeleri yapıldı.

Bulgular: Hastalarımızın hepsinde Sprengel deformitesi (yüksek skapula), servikal füzyon anomalisi, boyun hareketlerinde kısitll11k, kısa boyun, düşük saç çizgisi ve büyüme geriliği bulguları mevcuttu. Tüm hastalarımızda Büyüme Farklılaştırıcı Faktör 6 (GDF6) geni negatifti.

Sonuç: Tedavinin gerekliliği deformite ve diğer sistemik bulguların neden olabileceği patolojilere bağlıdır. KFS hastalarında küçük travma sonrası görülen nörolojik defisitler nedeniyle hasta temkinli olmalı ve ağır egzersizden kaçınmalıdır.

Anahtar Kelimeler: Klippel-Feil Sendromu, Sprengel Deformitesi, Servikal Füzyon Anomalisi, Kisa Boyun 


\section{INTRODUCTION}

Klippel-Feil Syndrome (KFS) is a congenital malformation caused by insufficiency in the segmentation of cervical somites on the 3-8th week of gestation. There is a short neck, fusion in the at least 2 cervical vertebrae and a decrease in neck movements in the classic triad. KFS patients may have higher risk for mechanical spinal cord injury because of unstable cervical segments. Although KFS generally occur as sporadic, the autosomal dominant, recessive and $\mathrm{X}$-linked forms also can be occurred $(1,2)$. Autosomal recessive (MEOXI and RIPPLY2) and dominant (GDF6 and GDF3) inheritance patterns were announced in KFS families (3). In the current article, we aimed to present our cases with KFS syndrome with clinical, radiological and genetic results.

\section{MATERIAL AND METHODS}

A total of 317 cervical MRIs between 20122019 years with various indications and 90 cervical CT reports in Duzce University, Faculty of Medicine, Research and Practice Hospital, Pediatric Surgery Department were included in the study. Ethical approval was obtained from the local ethics committee before starting work. Information was collected retrospectively with a file scan. Informed consent was obtained from all patients. The demographic, physical, radiological, genetic, biochemical, audiological, ocular, cardiologic examination of four cases with KFS (Sprengel deformity and cervical fusion anomalies) were carried out. For chromosomal analysis, $5 \mathrm{cc}$ peripheral blood samples of cases were cultured and metaphase plaques were obtained and $G$ banding was carried out. Also DNA was isolated from the peripheral blood samples of cases with KFS and GDF6 gene was sequenced.

Statistical Analysis: All statistical analyses were performed using IBM SPSS ${ }^{\circledR}$ Statistics for Windows ${ }^{\circledR}$, version 23.0 (IBM Corp., Armonk, NY, USA). The descriptive statistic was carried out.
All data are expressed as mean $\pm \mathrm{SD}$, min, max and percentage unless otherwise stated.

\section{RESULTS}

A total of 317 cervical MRIs required by Pediatric Surgery between 2012-2019 years with various indications and 90 cervical CT reports in 2019 were evaluated. 208 patients were female and 199 were male. In terms of gender, there was no significant difference $(\mathrm{p}=0.173)$ between the mean age of girls (11.1 \pm 5.9$)$ and the mean age of boys (10.3 \pm 5.5$)$. KFS findings were detected in 4 of these patients.

First case of KFS is 6-year-old female patient, first child of a 25-year-old mother (Gravidity3, Parturition2 and Alive2). Parents have not relationship and chronic diseases. Her parents age were 25-year-old. Her mother did not take any drugs during her pregnancy. She was born with normal spontaneous vaginal delivery (NSVD) at 40 weeks gestation. Patient's weight was $18 \mathrm{~kg}$ (lower than -0.67 SD) and her length was $112 \mathrm{~cm}$ (lower than -0.35 SD). She had normal mental level. Recurrent urinary tract infections and complaints in patients admitted to the pediatric surgery clinic with fecal incontinence were assessed as secondary to both constipation and there was no surgical pathology in patient. The patient's complaints improved with constipation and anal fissure treatment. Chest X - ray was showed Sprengel deformity (also known as High scapula) and cervical fusion anomalies. MRI, which was taken due to left shoulder impairment and scoliosis was present at the cervicothoracic level, and was consistent with the intramedullary syringohydromyelitis at the Th7-8 level, and was posterior fusion and anterior hemi vertebra at the C7-Th1 level. Also there was increase in the diameter of the vertebrae and spinal canal at the C3-4 level, and was a hemi vertebra view at the posterior of Th4-5 and a spinal canal at the midline of the bone septa (Diastometamyelia) (Figure 1).
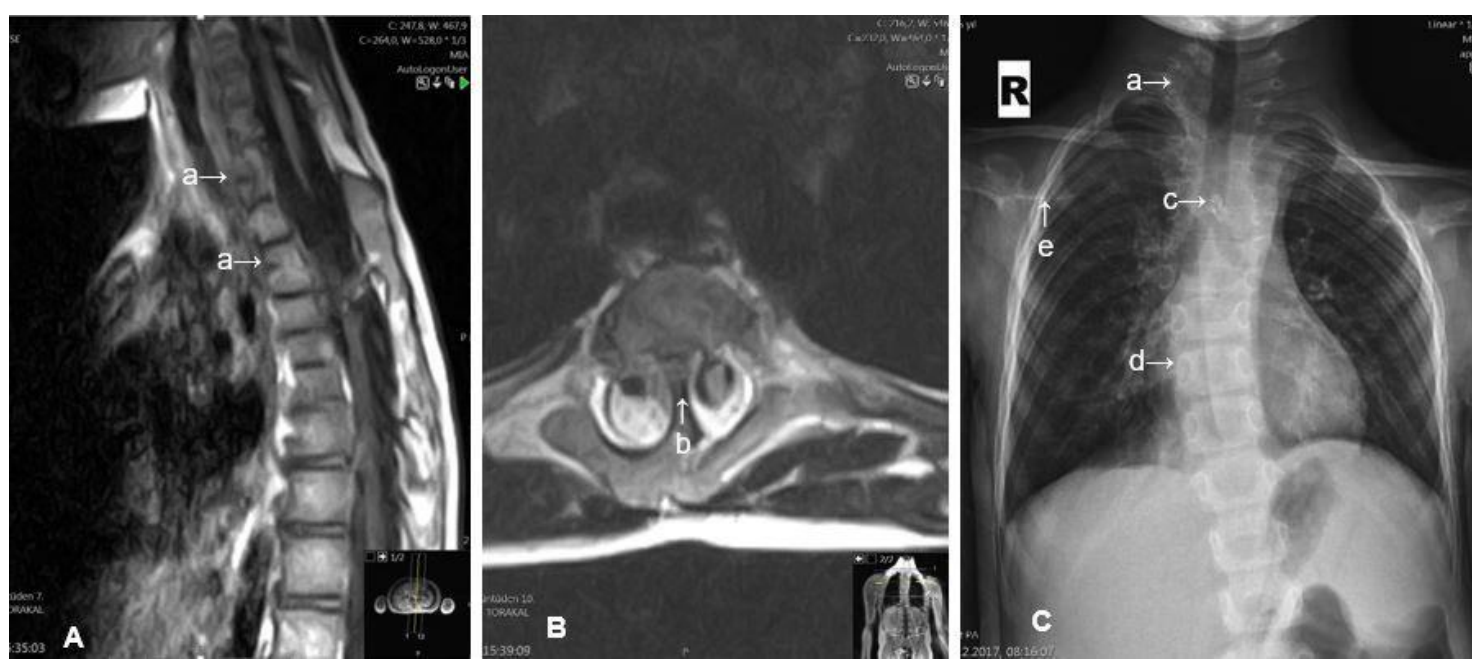

Figure 1. A; cervical fusion anomaly (a), B; hemi vertebra (b), C; bone septa image of diastematomyelia (c), scoliosis (d), high scapula (e) 
She has been treated with thyroid hormone replacement therapy for congenital hypothyroidism until the age of 3 , but currently not using drugs. The patient's audiological and ocular examination was normal. Electrocardiography and echocardiography findings were normal. Abdominal USG of the patient had a liver longitudinal dimension of 126 mm. (N:70-120). Routine biochemical analyses were normal. Her karyotype was 46, XX and sequencing analysis of GDF6 gene was normal. The clinical features of the case were given in Table 1.

Table 1. Clinical features of cases with KFS

\begin{tabular}{lllllllllllll}
\hline & HS & CFA & LNM & SN & LH & GR & S & OA & K & FR & GDF6 & AF \\
\hline Case1 & + & + & + & + & + & + & + & HM & $46, X X$ & - & - & $\begin{array}{l}\text { Diastometamyelia and } \\
\text { hypothyroidism }\end{array}$ \\
\hline Case2 & + & + & + & & & & & & & & &
\end{tabular}

Second case of KFS is 7 months old female patient, last child of a 27-year-old mother (Gravidity3, Parturition3 and Alive3). She was born with NSVD at 41 weeks gestation. Parents have not relationship and chronic diseases. Her parents age were 27-year-old. Her mother did not take any drugs during her pregnancy. Patient's weight was 7 $\mathrm{kg}$ (lower than -0.44 SD) and her length was $67 \mathrm{~cm}$ (higher than $0.76 \mathrm{SD}$ ). Her mental level was normal. Difficult defecation and anal bleedings were evaluated as secondary to both constipation and anal fissure in patients admitted to pediatric surgery and there was no surgical pathology in patient. The patient's complaints improved with constipation and anal fissure treatment. Chest X-ray was showed Sprengel deformity, cervical fusion and numerical deficiency in the right upper ribs anomalies (Figure2).

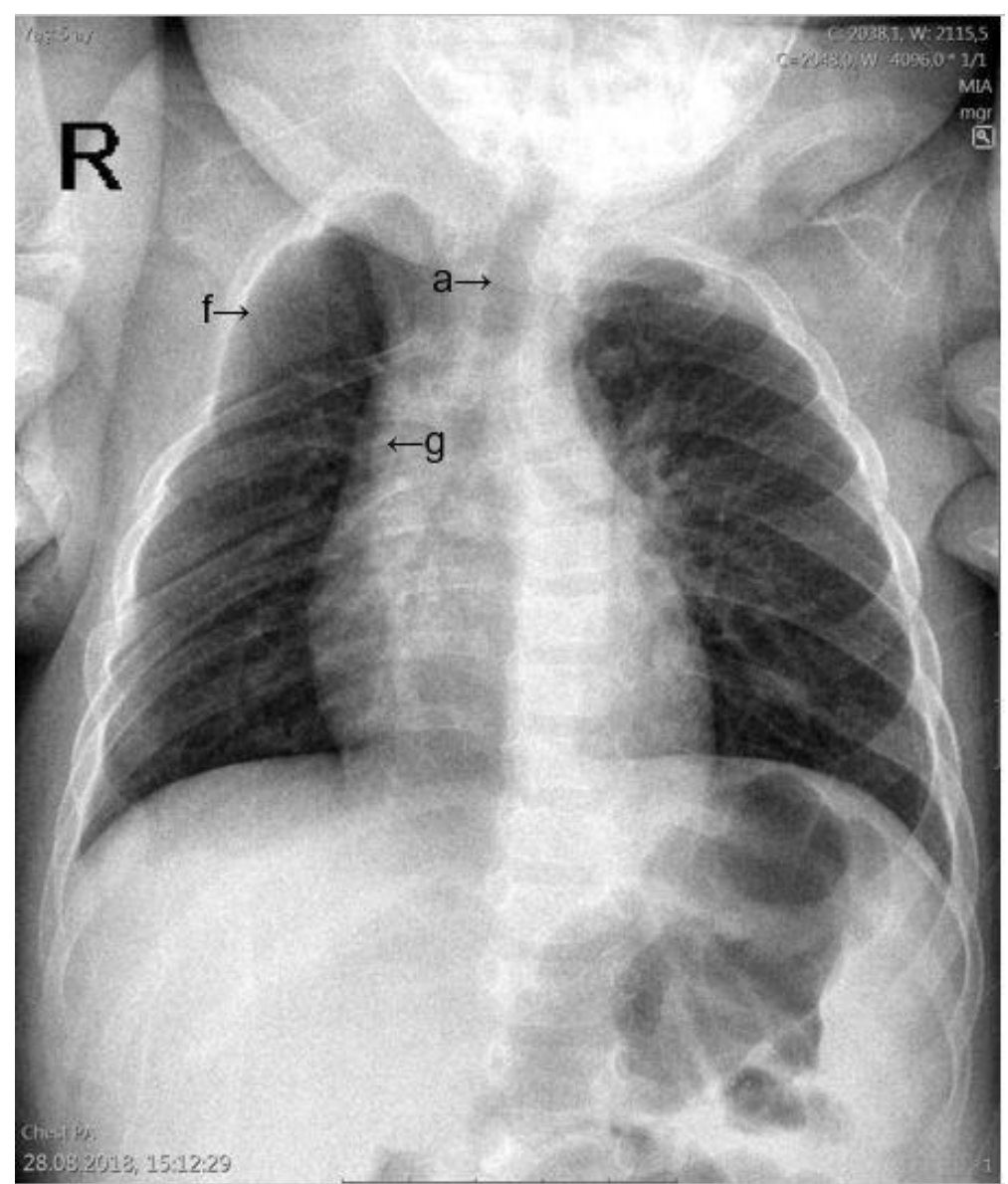

Figure 2. Cervical fusion anomaly (a), numerical deficiency in the right upper ribs (11 ribs) (f), fusion anomaly in ribs 2 and $3(\mathrm{~g})$ 
The patient's audiological and ocular examination was normal. Abdominal ultrasonography, electrocardiography, echocardiography and routine biochemical analyses were normal. Her karyotype was $46, \mathrm{XX}$ and sequencing analysis of GDF6 gene was normal. The clinical features of the case were given in Table 1.

Third case of KFS is last child of a 30-yearold mother (Gravidity5, Parturition2, Abortus2 and Alive1). There was no family relationship between her mother and father. The parents have not chronic diseases. Her mother's was 30-year-old and father's was 35-year-old. Her mother did not take any drugs during her pregnancy. First gravidity was 9-yearold male, alive and healthy. Second gravidity was aborts. Third gravidity was aborts. Fourth gravidity was curettage. Fifth gravidity was our patient. She was born at 39 weeks gestation with a birth weight of $4200 \mathrm{gr}$ by cesarean section (C/S) due to diagnosis of intrauterine hydrocephalus. Her first
Apgar score was 8 at the time of birth. Macrocephaly, short neck, right choanal atresia, high palate and low ears findings were detected in the patient's physical examination. The patient was admitted to the neonatal intensive care unit for respiratory distress and remained about 1 month. Patient's weight was 5300 gr (lower than -0.11 SD) and her length was $50 \mathrm{~cm}$ (lower than $-5.21 \mathrm{SD}$ ). The patient had severe mental motor retardation (MMR). Chest X - ray was showed Sprengel deformity and cervical fusion anomalies. The patient's audiological and ocular examination was normal. Her cranial computerized tomography revealed a significant enlargement in the third and bilateral lateral ventricles consistent with massive hydrocephalus and there was severe thinning of the brain parenchymal thickness, especially in the lateral and posterior segments, and this view was evaluated as significant in terms of hydrocephaly (Figure3).
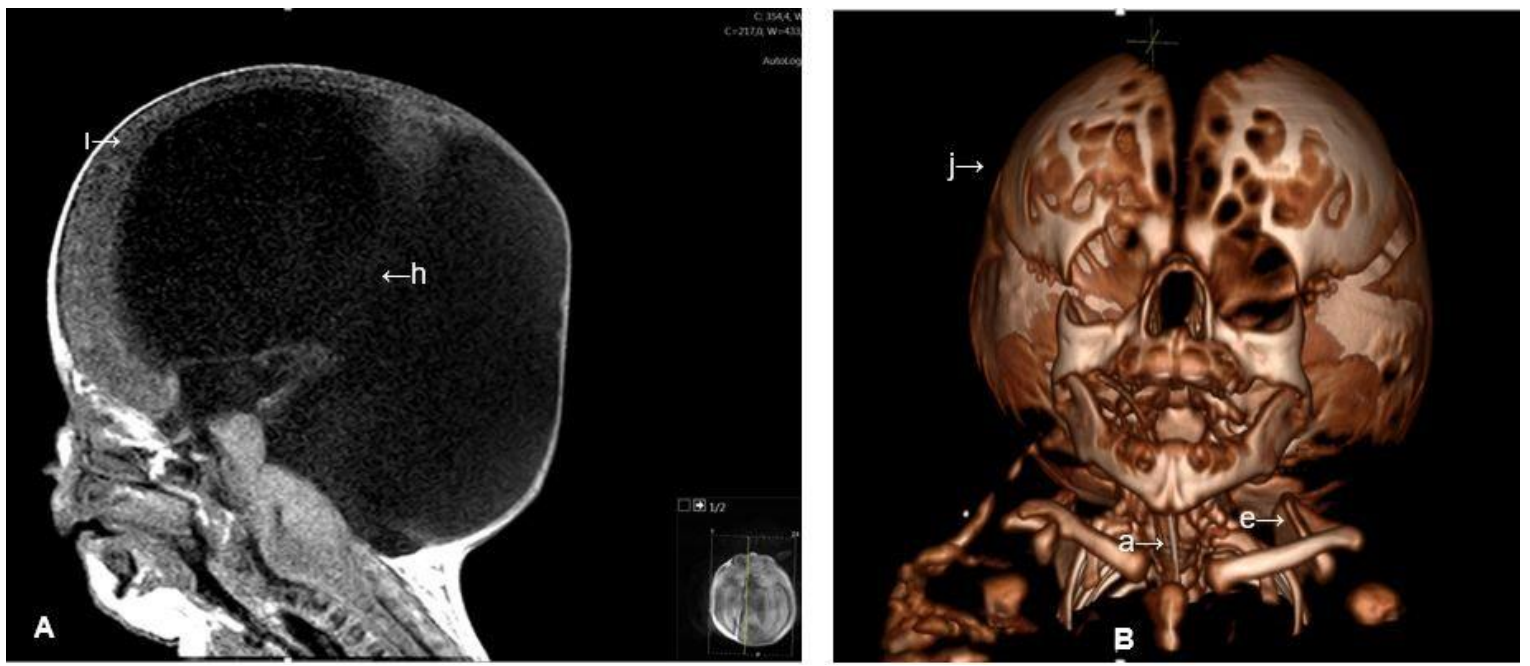

Figure 3. A; severe hydrocephalus (h) and severe thinning of the brain parenchyma (1), B; cervical fusion anomaly (a), high scapula (e), massive macrocephaly (j)

Abdominal

ultrasonography, electrocardiography, echocardiography findings and routine biochemical analyses were normal. Her karyotype was 46, XX and sequencing analysis of GDF6 gene was normal. Because of the possibility of difficult intubation due to short neck and cervical fusion anomaly, anesthesia approval could not be obtained. Thus ventriculoperitoneal shunt planned by brain surgery and the gastrostomy opening planned by the children's surgery was not done. The patient underwent ventriculostomy by brain surgery at the bedside and she referred to the external center for shunt surgery. The patient was admitted to the pediatric intensive care unit with respiratory distress again 2 months later. In her anamnesis, since the brain parenchymal thickness was severely thinner, she was considered inoperable, and shunt operation was not performed. On day 3 of hospitalization, patient was died because of the cardiopulmonary arrest. The clinical features of the case were given in Table 1. Fourth case of KFS is last child of a 42-year-old mother (Gravidity2, Parturition2 and Alive2). She had a healthy sister at 16-year-old. Her parents were 42-years old and have not relationship and chronic diseases. The cases' mother had used antibiotics due to the bronchitis during pregnancy. She was born at 38 weeks gestation by $\mathrm{C} / \mathrm{S}$ because of fetal distress. She was 9-year-old girl and had growth retardation and congenital unilateral renal agenesis. Patient's weight was $19.6 \mathrm{~kg}$ (lower than -2.33 SD) and her length was $118 \mathrm{~cm}$ (lower than -2.44 SD). She had normal mental level. She had prominent forehead, short neck, and low posterior hairline, limitation of the movement of head and neck, scoliosis, bilateral Sprengel deformity and congenital unilateral renal agenesis. She had strabismus, amblyopia, normal hearing and pediatric echocardiography. Vertebral fusion related with $\mathrm{C} 7-\mathrm{T} 1$ and also spinous process fusion at C5-T1 and T3-T5 levels were detected in 
cervical MR. Cervical kyphosis, the fusiform enlargement of the spinal canal between C6-T2, increased thickness of the cervical spinal cord at C5-T1 level were detected (Figure 4). According to renal scan, both kidneys were not seen normal position. Also while one of them showed renal agenesis, the other had ectopic location and normal function. No surgical pathology was found in the pediatric patient due to abdominal pain. Routine biochemical analyses were normal. Her karyotype was 46, XX and sequencing analysis of GDF6 gene was normal. The clinical features of the case were given in table 1 .Writing informed consent was taken from all cases.

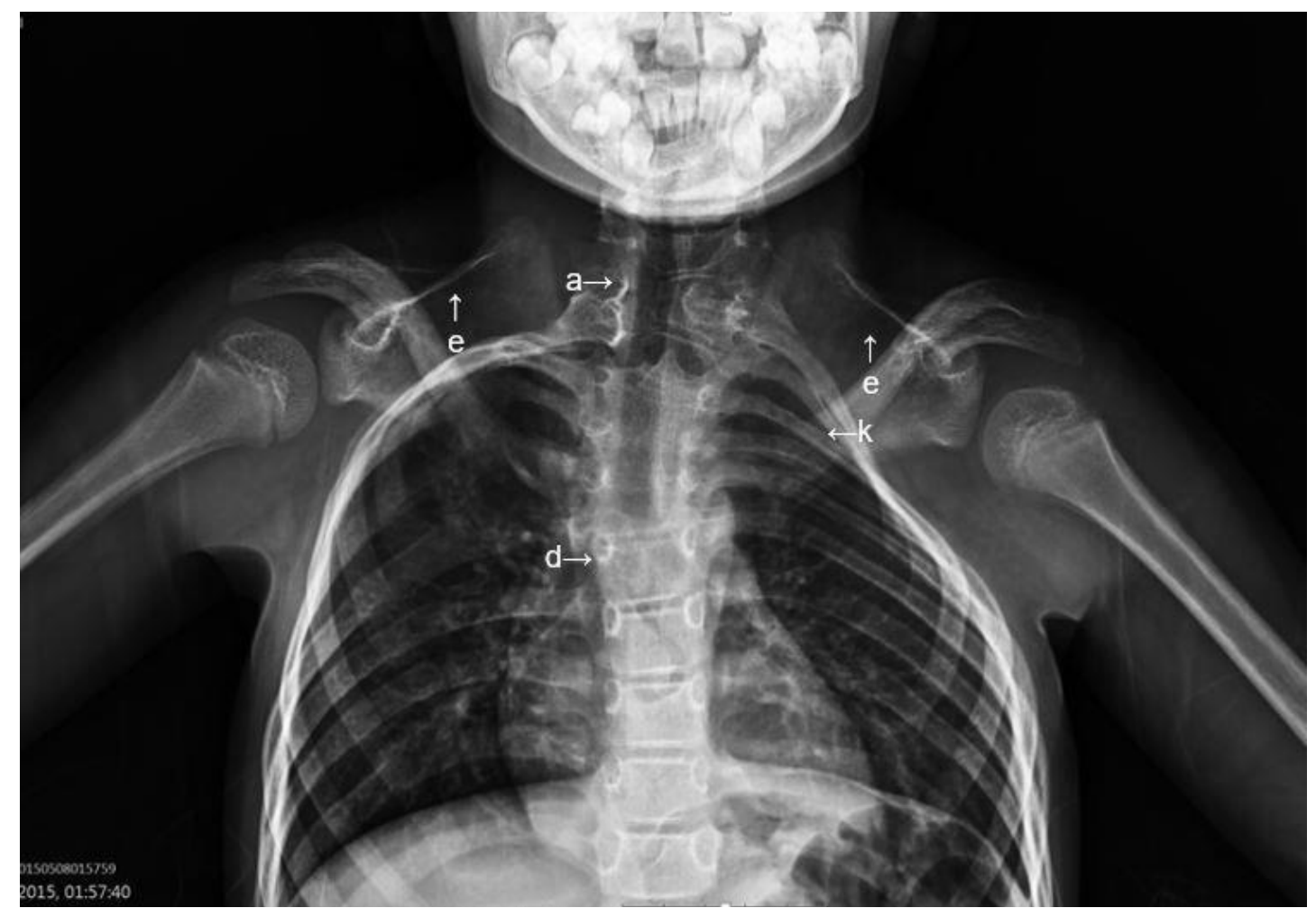

Figure 4. Cervical fusion anomaly (a), scoliosis (d), high scapula (e), deformity in the left upper ribs (k)

\section{DISCUSSION}

KFS was first described in 1912 by Klippel and Feil. It is occurred in common heterogeneous group of cases with cervical spine fusion. The frequency of disease is one in 40000-42000 births (4). Radiographic examination is difficult in infants and children and so there are differences between patients compared to adults. Patients should be examined extensively, since it is likely that many anomalies may accompany to KFS. In addition to cervical spine radiographs, thoracic and lumbar spine radiographs should be performed in order to investigate possible other anomalies and scoliosis development in all patients with KFS. Scoliosis and/or kyphosis (60\%), Sprengel deformity (30\%) and skeletal anomalies such as torticollis, urinary system anomalies (35\%), hearing loss (30\%), asymmetry on face and ascension $(20 \%)$, synkinesis or mirror movements (20\%), congenital heart diseases $(4 \%)$ can be detected in cases with KFS (5). All of our patients had Sprengel deformity, cervical fusion anomaly, restricted neck movements, short neck, low hairline and growth retardation. Scoliosis was present in our first and fourth patients. Hepatomegaly in our first patient and unilateral renal agenesis in our fourth patients were detected. The karyotypes of all our patients were $46, \mathrm{XX}$. There was no relationship between their mothers and their fathers. GDF6 gene was negative in all our patients. In our first patient, there were hypothyroidism and diastometamyelia in addition to routine findings. In our second patient, there was numerical deficiency in the right upper ribs in addition to routine findings. In our third patient, there were hydrocephalus, right choanal atresia, high palate, low ear and MMR in addition to routine findings. In our fourth patient, there were strabismus and amblyopia in addition to routine findings (Table 1).

KFS generally appear as sporadic but also autosomal dominant, recessive, and X-linked forms are seen (6). Mutations in KFS and GDF6 (Growth Differentiating Factor 6) and GDF3 (Growth Differentiating Factor 3) genes were found to be closely related (7). These growth factors are involved in the transforming growth factor beta group and play a role in the formation and elongation of cartilage and bone. GDF6 is primarily involved in the formation of the spine. However, it is not possible to find these gene mutations in all patients with KFS. This explains a wide variety of 
anomalies in KFS. The resulting GDF6 and GDF3 mutations are inherited in two ways; C2-C3 is autosomal dominant in segmentation defect, or is autosomal recessive in C5-C6 segmentation defect (8). An autosomal dominant transient gene copy is sufficient for the development of the disease, but in autosomal recessive transition, there is a need for double corrupted gene copy. In our cases, the GDF6 gene was evaluated but the mutations were not detected in this gen. Also family history was not detected in each case.

Because of airway management involved difficult tracheal intubation, it was obligated to secure the field of operation. Additionally careful postoperative care and respiratory management are necessary for the patient with KFS (9). In our case 3 , ventriculoperitoneal shunt planned by brain surgery and the gastrostomy opening planned by the children's surgery was not performed because of the short neck and cervical fusion anomaly; anesthesia approval could not be obtained.

\section{CONCLUSIONS}

The necessity of treatment depends more on the pathologies that may be caused by deformity and other systemic findings. The patient should be cautious and avoid heavy exercise because of neurological deficits seen after minor trauma in patients with KFS.

\section{REFERENCES}

1. Giampietro PF, Raggio CL, Blank RD, et al. Clinical, genetic and environmental factors associated with congenital vertebral malformations. Mol Syndromol. 2013(4):94-105.

2. Eroz R, Dogan M, Bolu S, et al. A seven years old girl with Klippel-Feil Syndrome, bilateral Sprengel deformity, congenital unilateral renal agenesis and a heterozygous mutation $\mathrm{M} 680 \mathrm{I}(\mathrm{G}>\mathrm{C})$ in the $\mathrm{MEFV}$ gene. Konuralp Medical Journal. 2017;9(2):167-170.

3. Karaca E, Yuregir OO, Bozdogan ST, et al. Rare variants in the notch signaling pathway describe a novel type of autosomal recessive Klippel-Feil syndrome. Am J Med Genet. Part A 2015;9999A:1-5.

4. Thomsen MN, Schneider U, Weber M, et al. Scoliosis and congenital anomalies associated with Klippel-Feil syndrome types I-III. Spine J. 1997;22(4):396-401.

5. Mahiroğullari M, Ozkan H, Yildirim N, et al. Klippel-Feil syndrome and associated congenital abnormalities: evaluation of 23 cases. Acta Orthop Traumatol Turc. 2006;40(3):234-9.

6. Moses JT, Williams DM, Rubery PT, et al. The prevalence of Klippel-Feil syndrome in pediatric patients: analysis of 831 CT scans. J Spine Surg. 2019;5(1):66-71.

7. Gruber J, Saleh A, Bakhsh W, et al. The Prevalence of Klippel-Feil Syndrome: A Computed TomographyBased Analysis of 2,917 Patients. Spine Deform. 2018;6(4):448-53.

8. Menger RP and Notarianni C. Klippel Feil Syndrome. 2019 Feb 22. StatPearls [Internet]. Treasure Island (FL): StatPearls Publishing; 2019. Available from http://www.ncbi.nlm.nih.gov/books/NBK493157/PubMed PMID: 29630209.

9. Hitosugi T, Tsukamoto M and Yokoyama T. Anesthetic management for twice in a child with Klippel-Feil Syndrome. Masui. 2017;66(5):554-7. 